\title{
An Investigation of Music Teacher Candidates' Performance Anxiety Levels in Piano Examinations
}

\author{
Deniz Beste Çevik Kılıç ${ }^{1}$ \\ ${ }^{1}$ Necatibey Faculty of Education, Balıkesir University, Balıkesir, Turkey \\ Correspondence: Deniz Beste Çevik Kılıç, Department of Music Education, Division of Fine Arts Education, \\ Necatibey Faculty of Education, Balıkesir University, Balıkesir, Turkey. Tel: 90-266-241-1212. E-mail: \\ beste@balikesir.edu.tr
}

Received: October 31, 2017

Accepted: December 6, 2017 Online Published: January 19, 2018

doi:10.5539/jel.v7n1p299

URL: https://doi.org/10.5539/jel.v7n1p299

\begin{abstract}
Examination anxiety in piano education, one of the important courses in music education, can negatively affect both success in examinations and the education of students. This study aimed to determine the anxiety levels of students in the music education departments of universities in western Turkey regarding their piano examinations and their significance according to different variables. The study sample consisted of 174 female and 107 male students. The study found the students' performance anxiety levels related to piano examinations to be moderate. There were no statistically significant differences in their anxiety levels by gender or age. Students with their own pianos were less likely to have performance concerns regarding piano examinations than those without. It was also found that the students' year of study had a significant effect on their performance anxiety levels in piano examinations.
\end{abstract}

Keywords: music teacher candidates, piano, performance, examination anxiety

\section{Introduction}

Anxiety is a persistent and generalized fear response (Harriman, 1970). In another definition, anxiety is treated as feeling threatened by a failure to achieve an obligation due to lack of competence, control or self-esteem (Fiske \& Morling, 1996). According to Barlow (2000), anxiety is a mixture of innate feelings that are altered by learning and experience. Barlow (2000) draws a model in which the anxiety-ridden individual interacts with various components. The emotion at the center of this model is an uncontrollable feeling that focuses on potential future threats, dangers and other adverse events.

Individuals experience anxiety in a variety of situations from time to time. It is a normal human feeling, except when it is extremely intense (Endler \& Kocovski, 2001). Average concern is a normal part of life. Here are anxiety's basic features:

- The anxiety-ridden person believes that their actions must be "perfect" on stage, or the disaster is disastrous (Steptoe \& Fidler, 1987).

- Somatic anxiety indicators such as tremors, rapid breathing or palpitation during performance (Conklin, 2011).

- Behavioral features such as the avoidance of performance-based activities (Clark \& Agras, 1991).

If anxiety is intense, prolonged or disrupts other parts of life, it becomes a psychological disorder (Bernstein, Clarke-Stewart, Roy, Srull, \& Wickens, 1994). Living in an intense manner in stressful situations increases individual anxiety levels (Endler \& Kocovski, 2001). A disturbed person lives with symptoms such as restlessness, fear, panic and excitement (Carr, 2001). A student with low anxiety is more willing to learn and more confident and a highly anxious student feels self-doubt (Baştürk, 2007, p. 167). Excessive anxiety negatively affects performance.

Music performance anxiety been discussed in the literature by music educators and psychologists in recent years and can occur in any situation (Osborne \& Franklin, 2002). One of these situations is performance. Concerns about musicians' performance anxiety, stage anxiety and performance anxiety are also discussed (Fehm \& Schmidt, 2006). Osborne, Kenny, \& Holsomback (2005) state that individuals who are involved in musical activities can experience increased anxiety about performance and success in front of crowds. According to Wesner, Noyes, \& 
Davis (1990), the most commonly used definition of performance anxiety is the experience of worrying about the failure of performance abilities before audiences, irrespective of musical abilities, education and degree of preparation. Performance concern affects amateurs (Steptoe \& Fidler, 1987), professional musicians, soloists, orchestra musicians and opera musicians (Kenny, Davis, \& Oates, 2004). Many studies have focused on the fact that it is one of the most important causes of the difficulties experienced by performing musicians and affects people of almost every age group and skill level (Sadler \& Miller, 2010).

Other studies have examined the causes of music performance anxiety (Tamborrino, 2001); differences by solo and group performance (Kane, 2008), the influence of performance conditions (Brotons, 1994), its relation to various psychological characteristics (Kageyama, 2007; Yoshie, Kudo, \& Ohtsuki, 2008) and treatment (Feener, 2004). One study emphasized that performance anxiety is widespread in professional musicians and music students and that concerns may vary (Steptoe \& Fidler, 1987). Some musicians and music students who experience anxiety have found their profession and performance affected in a negative way (Fehm \& Schmidt, 2006; Powell, 2004). Of professional musicians, $59 \%$ say that they experience severe performance anxiety (van Kemenade, van Son, \& van Heesch, 1995) and 70\% of them are affected negatively by it (Brodsky, 1996). Ryan and Andrews (2009) found that the presence and size of audiences affects levels of performance anxiety, which occurs most often in solo performances. Another study found that 91 of 155 professional musicians experienced musical performance anxiety "at a level that can affect professional music lives or lives". A large percentage of musicians are anxious in the days before performance $(36 \%)$, but some are anxious weeks $(10 \%)$, even months $(5 \%)$ beforehand. These results show that performance anxiety is a serious professional problem (van Kemenade, van Son, \& van Heesch, 1995).

Performance anxiety involves physical, mental and behavioral symptoms (Carr, 2001). The physical symptoms are easiest to distinguish measure and observe (Ely, 1991). They include cold hands, sweating, nausea, nausea, increased heart rate, paleness and muscle tension (Lehmann et al., 2007; Taborsky, 2007). Although physical manifestations are described in the literature as general anxiety and performance anxiety, there are not many indications about their frequency (Fehm \& Schmidt, 2006; Miller, 2004; Rosenthal \& Schreiner, 2000). These symptoms can affect musical performance negatively by appearing immediately before or during performances. The mental dimension of performance anxiety includes concerns about the individual's performance quality (Steptoe, 1989). One study emphasized that musicians' expectations of performance errors are in the mental dimension of performance anxiety (Fehm \& Schmidt, 2006). In the behavioral dimension of the performance anxiety, physical and mental performance anxiety result in a tense facial expression, concert cancellations and reduced performance quality (Conklin, 2011). In the behavioral dimension, the literature reports lack of concentration, poor rhythm, missed notes and postponed and missed examinations (Fehm \& Schmidt, 2006; Kenny, 2006).

The knowledge of the examination learned before the examination and all the studies done for the examination and the examination anxiety that prevented the whole preparation from being used effectively during the examination and which led to the failure of the examination is a living concern about the performance which will be shown at the examination (Fehm \& Schmidt, 2006). According to Spielberger (1970), examination anxiety is the emotional state that prevents individuals from performing at their actual ability level in a formal examination or evaluation and creates tension in them (p. 14), meaning that everyone can experience examination anxiety. Examination anxiety can also be experienced in instrument and piano examinations. In music education in Turkey, four years of piano course are required. The piano courses are based on performance, which is an outcome of the students' psychomotor behavior. The final examinations of the course are conducted by jury evaluation, and students perform with their own piano teachers and other piano instructors present. Musicians are more anxious when their performance is assessed by an expert jury (Fehm \& Schmidt, 2006; Kokotsaki \& Davidson, 2003). Another study emphasized that when people perform, they may become uncomfortable with others observing them, experience the audience as a threat and be unable to perform as desired (Dalkıran, Baltacı, Karataş, \& Nacieci, 2014). Taborsky (2007) states that when students perform for juries, their worries increase.

Music performance requires attention, memory, coordination and motor skills for success (Kenny, 2006). Discipline, attention to detail and the ability to play long pieces are also important (Kenny, Davis, \& Oates, 2004). Therefore, students must prepare well for examinations to avoid performance anxiety. Inadequate preparation is an important factor in performance anxiety (Kenny, 2006), and it can vary by degree of difficulty (Abel \& Larkin, 1990). Knowledge about the style of the pieces being performed can help students to be comfortable interpreting them. Lack of preparedness causes lack of self-confidence. Not being disciplined and assigning pieces above the students' ability levels increase the fear of making mistakes and performance anxiety (Ely, 1991). 
While individuals with normal levels of anxiety view examinations as an opportunity to reveal their achievements, anxiety-ridden individuals perceive them as threatening. Low anxiety affects performances positively, while high anxiety affects them negatively, making it impossible to perform well (Fehm \& Schmidt, 2006). Köknel (2005) notes that high levels of examination anxiety can prevent students from playing the instrument, such as excitement and muscle tension. Nagel (2010) emphasizes that during examination, students get over-excited about the idea that they may make mistakes. This research aims to reveal the variables in the performance anxiety levels of music teacher undergraduate students' piano examinations. This research is important because it contributes to the literature on music performance anxiety and makes suggestions to help with this problem.

\section{Methodology}

\subsection{Study Sample}

The sample included 281 music teachers in the departments of music education of three universities in western Turkey in the 2016-2017 academic year. Their personal characteristics are shown in Table 1.

Table 1. Distribution of students by personal characteristics

\begin{tabular}{|c|c|c|c|}
\hline & & $\mathrm{f}$ & $\%$ \\
\hline \multirow[t]{3}{*}{ Gender } & Female & 174 & 61.9 \\
\hline & Male & 107 & 38.0 \\
\hline & Total & 281 & 100 \\
\hline \multirow[t]{3}{*}{ Having a piano of their own } & Yes & 68 & 24.1 \\
\hline & No & 213 & 75.8 \\
\hline & Total & 281 & 100 \\
\hline \multirow[t]{5}{*}{ Age } & $17-19$ years & 118 & 41.9 \\
\hline & $20-22$ years & 82 & 29.1 \\
\hline & $23-25$ years & 35 & 12.4 \\
\hline & 26 years or older & 46 & 16.3 \\
\hline & Total & 281 & 100 \\
\hline \multirow[t]{5}{*}{ Year of study } & $1 \mathrm{st}$ & 96 & 34.1 \\
\hline & 2nd & 71 & 25.2 \\
\hline & $3 \mathrm{rd}$ & 69 & 24.5 \\
\hline & 4 th & 45 & 16.0 \\
\hline & Total & 281 & 100 \\
\hline
\end{tabular}

Table 1 shows that $61.9 \%$ (174) of the students were females, and $38.0 \%$ (107) were males. Of them, $24.1 \%$ (68) had their own pianos, and $75.8 \%$ (213) did not. Of them, $41.9 \%$ (118) were in the $17-19$ age group, $29.1 \%$ (82) were in the $20-22$ age group, $12.4 \%$ (35) were in the $23-25$ age group and $16.3 \%$ (46) were older than 26 years of age. Of the students, $34.1 \%$ (96) were in the first year of study, $25.2 \%$ (71) in the second year of study, $24.5 \%$ in the third year of study and $16.0 \%$ in the fourth year of study.

\subsection{Data Collection Tools}

A personal information form and the Music Performance Anxiety Inventory for Young People were used to collect data.

Personal Information Form: A personal information form was created to obtain personal information from the participants. It includes questions about gender, piano ownership, age and year of study. 
This study used the Music Performance Anxiety Inventory for Adolescents (MPAI-A) developed by MS Osborne and DT Kenny (2005) as a data collection tool. It has 15 items, and the validity and reliability study of its Turkish form showed high internal consistency with a Cronbach's alpha coefficient of .783 (Kafadar, 2009). It is a valid and reliable measurement tool. In Osborne and Kenny's study, its reliability coefficient was .91. In this study, its reliability coefficient was .89 .

\subsection{Data Analysis}

This study used descriptive statistics to evaluate its data. Means and standard deviations were calculated to determine the performance anxiety levels of the music teacher candidates. The independent t-test (t-test) was used to determine anxiety disparity by gender and piano ownership. ANOVA for unrelated samples (one-way ANOVA) was performed for age and year of study. Cohen's d coefficient was calculated to determine the magnitude of the effect of the differences.

\section{Findings}

Table 2 shows the results of the data analysis of the students' performance anxiety levels.

Table 2. The arithmetic mean and standard deviation values of the students' performance anxiety levels

\begin{tabular}{llll}
\hline & $\mathrm{N}$ & $\boldsymbol{X}$ & $\mathrm{SD}$ \\
\hline Performance anxiety & 281 & 4.58 & 1.83 \\
\hline
\end{tabular}

As Table 2 shows, the students' level of performance anxiety regarding piano examinations was moderate $(X=4.58, \mathrm{SD}=1.83)$.

In this study, t-test analysis of independent groups was performed when the variances were homogeneous by gender and piano ownership. The difference is the effect size calculated by Cohen's d. The results are shown in Table 3.

Table 3. Results of the t-test analysis

\begin{tabular}{lllllllll}
\hline $\begin{array}{l}\text { Independent } \\
\text { Variables }\end{array}$ & Group & $\mathrm{N}$ & $\overline{\boldsymbol{X}}$ & $\mathrm{SD}$ & $\mathrm{t}$ & $\mathrm{sd}$ & $\mathrm{p}$ & $\begin{array}{l}\text { Cohen's } \\
\mathrm{d}\end{array}$ \\
\hline Gender & Female & 174 & 3.02 & .58 & .464 & .279 & .65 & - \\
& Male & 107 & 2.98 & .57 & & & & .726 \\
\hline Piano ownership & Yes & 68 & 2.31 & .53 & 7.86 & .279 & $.00^{*}$ & \\
& No & 213 & 2.77 & .42 & & & \\
\hline
\end{tabular}

Table 3 shows no statistically significant difference in performance anxiety levels by gender [ $\mathrm{t}=.464, \mathrm{p}>.05]$. The anxiety levels of the females ( $\overline{\boldsymbol{X}}=3.02, \mathrm{SD}=.58)$ and the males $(\overline{\boldsymbol{X}}=2.98, \mathrm{SD}=.57)$ were nearly the same. There was a statistically significant difference by piano ownership $[\mathrm{t}=7.86, \mathrm{p}<.05]$. Those who owned pianos $(X=2.31$, $\mathrm{SD}=.53)$ were less anxious than those who did not $(\bar{X}=2.77, \mathrm{SD}=.42)$. This difference had a high level of magnitude, which indicates the importance of piano ownership.

In this study, the students' performance anxiety levels related to piano examinations were compared by gender and year of study. One way ANOVA was used to determine whether there was a statistically significant difference between the variables and whether the variances were homogeneous. When there was a significant difference, the effect size was examined using Tukey analysis to reveal the groups that differed. The results of this analysis are shown in Table 4. 
Table 4. The results of one-way ANOVA

\begin{tabular}{|c|c|c|c|c|c|c|c|c|c|}
\hline Variable & Groups & $\mathrm{N}$ & $\bar{X}$ & $\mathrm{SD}$ & Mean Square & $\mathrm{F}$ & $\mathrm{p}$ & $\begin{array}{l}\text { Cohen's } \\
\text { d }\end{array}$ & Tukey \\
\hline \multirow[t]{4}{*}{ Age } & a) $17-19$ & 118 & 2.73 & .53 & .128 & .546 & $.611 * *$ & - & - \\
\hline & b) $20-22$ & 82 & 2.63 & .59 & .249 & & & & \\
\hline & c) $23-25$ & 35 & 2.55 & .36 & & & & & \\
\hline & d) 26 or older & 46 & 2.76 & .54 & & & & & \\
\hline \multirow[t]{4}{*}{ Year of study } & a) $1 \mathrm{st}$ & 96 & 2.83 & .46 & 3.254 & 14.218 & $.00^{*}$ & .267 & $a>b, c, d$ \\
\hline & b) 2nd & 71 & 2.66 & .44 & & & & & \\
\hline & c) $3 \mathrm{rd}$ & 69 & 2.61 & .42 & & & & & \\
\hline & d) 4th & 45 & 2.53 & .40 & & & & & \\
\hline
\end{tabular}

Table 4 shows that age $[\mathrm{F}(3,277)=.546 ; p>.05]$ had no statistically significant effect on the students' performance anxiety levels in piano examinations. Their year of study $[\mathrm{F}(3,277)=14.218 ; p<.05]$ did have a statistically significant effect on their performance anxiety levels in piano examinations. The effect size of year of study was moderate.

\section{Discussion, Conclusion and Recommendations}

Research has contributed to performance anxiety's conceptualization, classification and the identification of appropriate interventions (Clark, 2001; Kenny, 2005; Lazarus \& Abramowitz, 2004), revealing the need to explore the concept of anxiety. Music teacher candidates perform during both piano examinations and concerts throughout four years of piano training. Failure experienced once or several times can negatively affect piano learning and examination success because the examination anxiety experienced by students during piano examinations is an important determinant of their academic achievement. Some students may experience anxiety if they do not succeed in their long-term work. The need to recognize anxiety is self-evident in such situations because students know that they have to be able to perform for a jury in the examination. Music examination are one-time opportunities for students to do their best with no other chance to correct their mistakes (McCormick \& McPherson, 2003). Patston \& Osborne (2015) state that performance anxiety is not familiar to young musicians in particular, resulting in high levels of psychological stimulation. Anxiety can manifest itself in different forms such as worry, shame and examination anxiety (Hart, 2007). Examination by expert juries are more stressful for musicians and music students (Kenny, 2006, Kokotsaki \& Davidson, 2003; Rae \& McCambridge, 2004; Tobacky \& Downs, 1986; Wilson \& Roland, 2002).

Undoubtedly, considering the nature of the courses in the music teacher education program and the music teaching profession, music teacher candidates will perform on the piano as students and during their professional lives, whether as students or teachers. In all these cases, it is of great importance that music teacher candidates be less anxious and that they can be successful both in education and in their profession. This study was carried out to investigate whether music performance anxiety varies by gender, piano ownership, age or year of study. It suggests that music teacher candidates will increase their performance piano by reducing their anxiety levels in piano courses.

This research found that the performance anxiety levels of the students regarding piano examinations are moderate. There are various studies that have positively affected moderately anxious performance (Kenny, 2006, Papageorgi, Hallam, \& Welch, 2007). Papageorgi, Hallam \& Welch (2007) indicate that a moderate level of anxiety increases performance efficiency if controlled. Powell (2004) notes that examination anxiety is a type of performance anxiety, but that the motor performance, emotional and intellectual functioning of music performers can be negatively affected by it. As a result, people with low levels of anxiety can perform better for audiences (Parncutt $\&$ McPherson, 2002). Schwarzer (1988) sees examinations as an opportunity for success for individuals whose examination anxiety level is normal. Osborne \& Franklin (2002) found that individuals with low performance anxiety perceive audiences' evaluations positively. However, some studies emphasize that the number of people in 
the audience and their expertise in the subject increase performance anxiety (Iusca \& Dafinoiu, 2012; LeBlanc, Jin, Obert, \& Siivola, 1997). Miesner \& Maki (2007) found that students with high anxiety have negative attitudes toward examination committees and teachers. Sansgiry and Sail (2006) point out that students with high anxiety have difficulty understanding their education. They emphasize the need for educators to focus on the underlying causes of examination anxiety.

This study found no statistically significant difference in the undergraduate music students' performance anxiety levels regarding piano examinations by gender. Little (2010), in a study of the relation between music teacher candidates' examination anxiety, self-esteem and instrument achievement, found that gender had no effect on their examination anxiety levels, which supports this study's findings. Despite this result, there are studies showing that female musicians experience more performance anxiety than males (Dews \& Williams, 1989; Kenny, 2006; Miller, 2004; Osborne \& Franklin, 2002; Rae \& McCambridge, 2004; Rosenthal \& Schreiner, 2000; Yöndem, 2007). Ryan's (2004) study of 26 sixth graders' music performance anxiety by gender measured their heart rates and observed their movements. He concluded that females showed an increase in heart rate at every stage of performance and that males exhibited significant restlessness before and during performance. Studer et al. (2011) found that females' performance anxiety significantly differed from that of males, that they had a negative emotional response to music performance anxiety and that they complained of increased breathing rates in their study of 169 university music education students. LeBlanc, Jin, Obert, \& Siivola (1997) found increased heart rates in females with performance anxiety. Rae \& McCambridge (2004) found that female musicians had significantly higher performance anxiety levels than males in their research with 120 musicians.

In this study, the performance anxiety levels of the students varied significantly by their piano ownership. Those who owned pianos were less anxious than those who did not. This suggests that self-esteem increases and performance anxiety falls because students who own their own pianos spend more time playing the piano. The age of the students did not have a significant influence on the level of performance anxiety regarding piano examinations. A study of an Iowa music school's students found that, of 302 participants, $49 \%$ were influenced by music performance anxiety, $21 \%$ had anxiety during performance, and $16.1 \%$ had experience the negative effects of performance anxiety in their careers. It found that women have more anxiety than men and that there is no relationship between age and performance anxiety (Wesner et al., 1990). These findings support this study. There are also different research results about age's effect on music performance anxiety. Papageorgi, Creech, \& Welch (2011) found that perceived sensitivity to performance anxiety was related to gender, age, worry and self-esteem. Valentine (2003) notes that performance anxiety declines with age and experience. Thomas \& Nettelbeck (2013) found that musicians in the 12-18 age group have higher performance anxiety. Another survey determined that $22.8 \%$ of 330 German music students in the $20-23$ age group had high performance anxiety was (Fehm \& Schmidt, 2006; Schröder \& Liebelt, 1999). Kenny (2006) emphasizes that performance anxiety generally begins in the early stages of musical development and continues in adulthood, in a study of the relationship between adolescents' age and music performance anxiety. These results can be interpreted as the effect of age and more training on the performance anxiety levels, depending on the experiment.

This study also found that the students' year of study had a significant influence on their performance anxiety levels. Fourth-year students had the most anxiety and first-year students had the least. This suggests that fourth-year students are anxious about their graduation and the future. In addition, the fear of not being able to get a job after graduation creates anxiety for students. Performance may also rise because senior students cannot prepare enough for their piano examinations. Taborsky (2007) found that third-year students were more anxious than second-year students, which supports this study. Unlike these studies, Sadler \& Miller (2010) indicate that the musical performance anxiety of prospective teachers does not differ significantly by year of study. While this finding does not overlap with the findings of this research, Hamann (1982) notes that longer-term students gain experience with an increase in years of study, and that experienced students performed better in examinations than less experienced students. Another study of performance anxiety also found that experience increases with students' years of study (McQuade, 2009).

This research's findings suggest that:

- The individual differences of each student should be taken into account in the effort to identify and reduce anxiety. Its causes should be understood and specific approaches should be followed.

- It is important for music educators to take appropriate approaches to anxiety in the process of teaching performance skills to their students, which will contribute to the professional lives of music students by resolving their problems with anxiety as early as possible. 
- Further research on performance anxiety levels and methods of coping with piano examinations and treatments should be done.

- It may be advisable for students to reduce examination anxiety and organize activities such as in-class and public concerts.

- Piano instructors should teach students appropriate, planned and conscious work behaviors that can mitigate examination anxiety.

- Performance anxiety levels for piano examinations should examined by different variables and with a larger sample.

- Piano lecturers should guide students about how to be fully prepared for examinations.

- Piano instructors should set an example of self-reliance, not only in terms of technique, but also as models of self-confidence for their students.

\section{References}

Abel, J. L., \& Larkin, K. T. (1990). Anticipation of performance among musicians: Psychological arousal, confidence, and state anxiety. Psychology of Music, 18, 171-182. https://doi.org/10.1177/0305735690182006

Barlow, D. H. (2000). Unraveling the mysteries of anxiety and its disorders from the perspective of emotion theory. American Psychologist, 55(11), 1247-1263. https://doi.org/10.1037/0003-066X.55.11.1247

Baştürk, R. (2007). Kamu personeli seçme sınavına hazırlanan öğretmen adaylarının sınav kaygı düzeylerinin incelenmesi. Firat Üniversitesi Sosyal Bilimler Dergisi, 17(2), 163-176.

Bernstein, D. A., Clarke-Stewart, A., Roy, E. J., Srull, T. K., \& Wickens, C. D. (1994). Psychology. Üçüncü Basım. USA: Houghton Mifflin Company.

Brodsky, W. (1996). Music performance anxiety reconceptualised: A critique of current research practices and findings. Medical Problems of Performing Artists, 11, 88-98.

Brotons, M. (1994). Effects of performing conditions on music performance anxiety and performance quality. Journal of Music Therapy, 31(1), 63-81. https://doi.org/10.1093/jmt/31.1.63

Carr, A. (2001). Abnormal Psychology. London: Psychology Press.

Clark, D. B., \& Agras, W. S. (1991). The assessment and treatment of performance anxiety in musicians, American Journal of Psychiatry, 148, 598-605. https://doi.org/10.1176/ajp.148.5.598

Clark, D. M. (2001). A cognitive model of social phobia. In R. G. Heimberg, M. R. Liebowitz, D. A. Hope, \& F. R. Schneir (Eds.), Social phobia: diagnosis, assesment, and treatment. NY: The Guilford Press.

Conklin, N. M. (2011). Musical performance anxiety in virtual performances: A comparison of recorded andlive performance contexts. Unpublished Doctoral dissertation, University of Oklahoma.

Dalkıran, E., Şahin B., Karataş, H., Z., \& Nacakci, Z. (2014). Bireysel çalgı performans sınavı kaygı ölçeğinin geliştirilmesi: geçerlik-güvenirlik çalışması. International Journal of Assessment Tools in Education, 1(1), 13-25.

Dews, C. L. B., \& Williams, M. S. (1989). Student musician's personality styles, stresses and coping patterns. Psychology of Music, 17, 37-47. https://doi.org/10.1177/0305735689171004

Ely, M. C. (1991). Stop performance anxiety. Music Educators Journal, 78, 35-39. https://doi.org/10.2307/3398258

Endler, S. N., \& Kocovski, N.L. (2001). State and trait anxiety revisited. Journal of Anxiety Disorders, 15(3), 231-245. https://doi.org/10.1016/S0887-6185(01)00060-3

Feener, R. S. (2004). EMDR: Eye movement desensitization and reprocessing a new method in the treatment of performance anxiety for singers. Yayımlanmamış Doktora Tezi. ABD: The Florida State University, School of Music.

Fehm, L., \& Schmidt, K. (2006). Performance anxiety in gifted adolescent musicians. Journal of Anxiety Disorders, 20(1), 98-109. https://doi.org/10.1016/j.janxdis.2004.11.011

Fiske, S. T., \& Morling, B. (1996). Controlling self and others: A theory of anxiety, mental control and social control. Personality and Social Psychology Bulletin, 22(2), 115-124. https://doi.org/10.1177/0146167296222001 
Hamann, D. L. (1982). An assessment of anxiety in instrumental and vocal performances. Journal of Research in Music Education, 30(2), 77-90. https://doi.org/10.2307/3345040

Harriman, P. L. (1970). An outline of modern psychology. New Jersey: Littlefield, Adams \& Co.

Hart, R. (2007). Therapeutic response to performance anxiety: Extending clinical research into the experience of artistic performance with a sample of professional musicians. PhD. Dissertation, April.

Iuscaa, D., \& Dafinoiu, I. (2012). Performance anxiety and musical level of undergraduate students in exam situations: The role of gender and musical instrument. Procedia-Social and Behavioral Sciences, 33, 448-452. https://doi.org/10.1016/j.sbspro.2012.01.161

Kafadar, A. (2009). Piyanistler örneğinde müzisyenlere özgü performans anksiyetesi. Yayımlanmamış Yüksek Lisans Tezi. Dokuz Eylül Üniversitesi Güzel Sanatlar Enstitüsü, Müzik Anasanat Dalı, İzmir.

Kageyama, N. J. (2007). Attentional focus as a mediator in the anxiety-performance relationship: The enhancement of music performance quality under stress. Yayımlanmamıs doktora tezi. ABD: Indiana University, Department of Counseling Psychology.

Kane, K. L. (2008). An examination into the temporal patterning of emotions, cognitions, and coping strategies in instrumental performers. Yayımlanmamış doktora tezi. ABD: Florida State University, College of Education.

Kenny D. T., Davis P., \& Oates J. (2004). Music performance anxiety and occupational stress amongst opera chorus artists and their relationship with state and trait anxiety and perfectionism. Journal of Anxiety Disorders, 18, 757-777. https://doi.org/10.1016/j.janxdis.2003.09.004

Kenny, D. T. (2005). A systematic review of treatments for music performance anxiety. Anxiety, Stress and Coping, 18(3), 183-208. https://doi.org/10.1080/10615800500167258

Kenny, D. T. (2006). Music performance anxiety: origins, phenomenology, assessment and treatment. Journal of Music Research, 31, 51-64. Retrieved from http://www2.fhs.usyd.edu.au/bach/staff/kenny

Kokotsaki, D., \& Davidson, J. W. (2003). Investigating musical performance anxiety among music college singing students: A quantitative analysis. Music Education Research, 5(1), 45-59. https://doi.org/10.1080/14613800307103

Köknel, Ö. (2005). Kaygıdan Mutluluğa Kişilik. On yedinci basım, Altın Kitaplar yayınevi, İstanbul, s. 431.

Küçük, D. P. (2010). Müzik öğretmeni adaylarının sınav kaygısı, benlik saygısı ve çalgı başarıları arasındaki ilişkinin incelenmesi. Ahi Evran Üniversitesi, Eğitim Fakültesi Dergisi, 2(3), 37-50.

Lazarus, A. A., \& Abramowitz, A. (2004). A multimodal behavioral approach to performance anxiety. Journal of Clinical Psyhology, 60(8), 831-840. https://doi.org/10.1002/jclp.20041

LeBlanc, A., Jin, Y. C., Obert, M., \& Siivola, C. (1997). Effect of audience on music performance anxiety. Journal of Research in Music Education, 45(3), 480-496. https://doi.org/10.2307/3345541

Lehmann, A. C., Sloboda, J. A., \& Woody, R. H. (2007). Psychology for musicians: Understanding and acquiring the skills. Oxford: Oxford University Press. https://doi.org/10.1093/acprof:oso/9780195146103.001.0001

McCormick, J., \& McPherson, G. E. (2003). The role of self-efficacy in a musical performance examination: An exploratory structural equation analysis. Psychology of Music, 31, 37-51. https://doi.org/10.1177/0305735603031001322

McQuade, C. (2009). An investigation of the relationship among performance anxiety, perfectionism, optimisim, and self-efficacy in student performers. Yayımlanmamış doktora tezi. ABD: Fordham University, New York, School of Education.

Miesner, M. T., \& Maki, R. H. (2007). The role of test anxiety in absolute and relative meta comprehension accuracy. European Journal of Cognitive Psychology, 19(4/5), 650-670. https://doi.org/10.1080/09541440701326196

Miller, T. A. (2004). Why did it sound better in the practice room? A guide to music performance anxiety and how to cope with it through journal writing. Yayımlanmamıs doktora tezi. ABD: Michigan State University, Department of Music.

Nagel, J. J. (2010). Treatment of music performance anxiety via psychological approaches: A review of selected CBT and psychodynamic literature. Medical Problems of Performing Artists, 25(4), 141-148. 
Osborne, M. S., \& Franklin, J. (2002). Cognitive processes in music performance anxiety. Australian Journal of Psychology, 54(2), 86-93. https://doi.org/10.1080/00049530210001706543

Osborne, M. S., \& Kenny, D. T. (2005). Development and validation of a music performance anxiety inventory for gifted adolescent musicians, Anxiety Disorders, 19, 725-751. https://doi.org/10.1016/j.janxdis.2004.09.002

Osborne, M. S., Kenny, D. T., \& Holsomback, R. (2005). Assessment of music performance anxiety in late childhood: A validation study of the MPAI-A. International Journal of Stress Management, 12(4), 312-330. https://doi.org/10.1037/1072-5245.12.4.312

Papageorgi, I., Creech, A., \& Welch, G., (2011). Perceived performance anxiety in advanced musicians specializing in different musical genres. Psychology of Music, 41(1), 18-41. https://doi.org/10.1177/0305735611408995

Papageorgi, I., Hallam, S., \& Welch, G. F. (2007). A conceptual framework for understanding musical performance anxiety. Research Studies in Music Education, 28(1), 83-107. https://doi.org/10.1177/1321103X070280010207

Parncutt, R., \& McPherson, G. (2002). Science and Psychology of Music Performance (p. 48). Oxford University Press, New York. https://doi.org/10.1093/acprof:oso/9780195138108.001.0001

Patston, T., \& Osborne, M. S. (2015). The developmental features of music performance anxiety and perfectionism in school age music students. Performance Enhancement \& Health, 4(1-2), 42-49. https://doi.org/10.1016/j.peh.2015.09.003

Powell, D. H. (2004). Treating individuals with debilitating performance anxiety: An introduction. Journal of Clinical Psychology, 60(8), 801-808. https://doi.org/10.1002/jclp.20038

Rae, G., \& McCambridge, K. (2004). Correlates of performance anxiety in practical music exam. Music and Psychology Research, 32(4), 432-439. https://doi.org/10.1177/0305735604046100

Rosenthal, B. S., \& Schreiner, A. C. (2000): Prevalence of psychological symptoms among undergraduate students in an ethnically diverse urban public college. Journal of American College Health, 49(1), 12-18. https://doi.org/10.1080/07448480009596277

Ryan, C. (2004). Gender differences in children's experience of musical performance anxiety. Psychology of Music, 32, 89-103. https://doi.org/10.1177/0305735604039284

Ryan, C., \& Andrews, N. (2009). An investigation into the choral singer's experience of music performance anxiety. Journal of Research in Music Education, 57(2), 108-126. https://doi.org/10.1177/0022429409336132

Sadler, M. E., \& Miller, C. J. (2010). Performance anxiety: A longitudinal study of the roles of personality and experience in musicians. Social Psychological and Personality Science, 1(3), 280-287. https://doi.org/10.1177/1948550610370492

Sansgiry, S. S., \& Sail, K. (2006). Effect of students' perceptions of course load on test anxiety. American Journal of Pharmaceutical Education, 70(2), 1-6. https://doi.org/10.5688/aj700226

Schwarzer, R. (1988). Worry and emotionality as separate componenets in test anxiety. International Review of Applied Psychology, 33, 205-220. https://doi.org/10.1111/j.1464-0597.1984.tb01429.x

Spielberger, C. D. (1970). Anxiety as emototional state, anxiety currents trend in theory on research (pp. 23-43). New York: Academic Press.

Steptoe, A. (1989). Stress, coping and stage fright in professional musicians. Psychology of Music, 17(1), 3-11. https://doi.org/10.1177/0305735689171001

Steptoe, A., \& Fidler, H. (1987). Stage fright in orchestral musicians: A study of cognitive and behavioural strategies in performance anxiety. British Journal of Psychology, 78, 241-249. https://doi.org/10.1111/j.2044-8295.1987.tb02243.x

Studer, R., Danuser, B., Hildebrant, H., Arial, M., \& Gomez, P. (2011). Hyperventilation complaints in music performance anxiety among classical music students. Journal of Psychomatic Research, 70, 557-564. https://doi.org/10.1016/j.jpsychores.2010.11.004

Taborsky, C. (2007). Musical performance anxiety: A review of literature. Update: Applications of Research in Music Education, 26, 15-25. https://doi.org/10.1177/87551233070260010103 
Tamborrino, R. A. (2001). An examination of performance anxiety with associated solo performance of college level music majors. Dissertation Abstracts International, 62, 1636.

Thomas, J. P., \& Nettelbeck, T. (2013). Performance anxiety in adolescent musicians. Psychology of Music, 42(4), 624-634. https://doi.org/10.1177/0305735613485151

Tobacyk, J. J., \& Downs, A. (1986). Personal construct threat and irrational beliefs as cognitive predictors of increases in musical performance anxiety. Journal of Personality and Social Psychology, 51(4), 779-782. https://doi.org/10.1037/0022-3514.51.4.779

Valentine, E. (2003). The fear of performance. In J. R. Londra (Ed.), Musical performance, a guide to understanding (pp. 168-182). Cambridge University Press.

Van Kemenade, J. F., Van Son, M. J., \& Van Heesch, N. C. (1995). Performance anxiety among Professional musicians in symphonic orchestras: A Self-Report Study. Psychological Reports, 77(2), 555-562. https://doi.org/10.2466/pr0.1995.77.2.555

Wesner, R. B. R., Noyes, Jr., \& Davis, T. L. (1990). The occurence of performance anxiety among musicians, Journal of Affective Disorders, 18, 177-185. https://doi.org/10.1016/0165-0327(90)90034-6

Wilson, G. D., \& Roland, D. (2002). Performance anxiety. In R. Parncutt \& G. E. McPherson (Eds.), The science and psychology of music performance (pp. 47-61). Oxford: Oxford University Press. https://doi.org/10.1093/acprof:oso/9780195138108.003.0004

Yoshie, M., Kudo, K., \& Ohtsuki, T. (2008). Effects of psychological stress on state anxiety, electromyographic activity and arpeggio performance in pianists. Medical Problems of Performing Artists, 23, 120-132.

Yöndem, Z. D. (2007). Performance anxiety, dysfunctional attitudes and gender in university students. Social Behavior and Personality, 35(10), 1415-1426. https://doi.org/10.2224/sbp.2007.35.10.1415

\section{Copyrights}

Copyright for this article is retained by the author(s), with first publication rights granted to the journal.

This is an open-access article distributed under the terms and conditions of the Creative Commons Attribution license (http://creativecommons.org/licenses/by/4.0/). 